\title{
EMP1 Gene
}

National Cancer Institute

\section{Source}

National Cancer Institute. EMP1 Gene. NCI Thesaurus. Code C18454.

This gene is involved in cell-cell interactions and the regulation of cellular proliferation, 